\title{
Synthesis, docking, and in vitro activity of thiosemicarbazones, aminoacyl-thiosemicarbazides and acyl-thiazolidones against Trypanosoma cruzi
}

\author{
Ana Cristina Lima Leite, ${ }^{\mathrm{a}, *}$ Renata Souza de Lima, ${ }^{\mathrm{a}}$ Diogo Rodrigo de M. Moreira, ${ }^{\mathrm{a}}$ \\ Marcos Veríssimo de O. Cardoso, ${ }^{\mathrm{a}}$ Ana Carolina Gouveia de Brito, ${ }^{\mathrm{a}}$ \\ Luciene Maria Farias dos Santos, ${ }^{\mathrm{a}}$ Marcelo Zaldini Hernandes, ${ }^{\mathrm{b}}$ Alice Costa Kiperstok, ${ }^{\mathrm{c}}$ \\ Ricardo Santana de Lima $^{\mathrm{c}}$ and Milena B. P. Soares ${ }^{\mathrm{c}}$ \\ a Laboratório de Planejamento, Avaliação e Síntese de Fármacos-LABSINFA, Departamento de Ciências Farmacêuticas, \\ Universidade Federal de Pernambuco, Rua Prof. Artur Sá S/N, Cidade Universitária, 50740-520 Recife, PE, Brazil \\ ${ }^{\mathrm{b}}$ Laboratório de Química Teórica Medicinal-LQTM, Departamento de Ciências Farmacêuticas, Universidade Federal de \\ Pernambuco, Rua Prof. Artur Sá S/N, Cidade Universitária, 50740-520 Recife, PE, Brazil \\ ${ }^{\mathrm{c}}$ Centro de Pesquisas Gonçalo Moniz/FIOCRUZ_Rua Waldemar Falcão, 121, Candeal, 40296-750 Salvador, BA, Brazil
}

Received 29 September 2005; revised 12 January 2006; accepted 13 January 2006

Available online 3 February 2006

\begin{abstract}
A novel series of thiosemicarbazone and aminoacyl-thiazolidones derivatives were synthesized. Their structure suggests that these compounds could have anti-Trypanosoma cruzi activity. Biological evaluation indicates that some of these compounds are able to inhibit the growth of $T$. cruzi in concentrations non-cytotoxic to mammalian cells. Docking studies were carried out in order to investigate the binding pattern of these compounds for the $T$. cruzi cruzain (TCC) protein, and these showed a significant correlation with experimental data.
\end{abstract}

(c) 2006 Elsevier Ltd. All rights reserved.

\section{Introduction}

Chagas' disease is a serious health problem that affects around 20 million people in Central and South Americas. The protozoan Trypanosoma cruzi is the causative agent of this disease. Current therapy is based on nifurtimox and benznidazole, drugs capable of eliminating parasitaemia and reducing serological titers in the acute phase of infection but not effective for all $T$. cruzi strains, especially in the chronic phase of infection. In addition, these drugs may cause serious adverse side effects due to their high toxicity. ${ }^{1-4}$

To develop new drugs to combat parasitic infections, research is often directed toward key differences between the metabolism of the mammal and the parasite. For

\footnotetext{
Keywords: Thiosemicarbazones; Acyl-hydrazones; Aminoacyl-thiazolidones; Anti-Trypanosoma cruzi compounds; Docking studies.

* Corresponding author. Tel.: +0558133418511; fax: +0558121268510; e-mail: acllb2003@yahoo.com.br
}

this reason, cruzain (aka cruzipain) and trypanothione reductase (TR) are specific targets in the search for novel and selective inhibitors and subversive substrates. ${ }^{1,5}$

Cruzain is the major cysteine protease of $T$. cruzi, and is released at all life cycle stages of the parasite, but delivered to different cellular compartments at each stage. This enzyme is essential for replication of the intracellular parasite and appears to have potential for new antitrypanosomal chemotherapy. ${ }^{5}$

The forms of $T$. cruzi present in the human host are the bloodstream trypomastigote and the intracellular replicative amastigote. The epimastigote form, an obligate mammalian intracellular stage, has been confirmed recently. ${ }^{6}$ Since vaccinations against trypanosomatic infections are still under development, the need for new drugs is indisputable.

The trypanocidal activity of several aromatic and heterocyclic hydrazones and acyl-hydrazine-hydrazone has been reported. ${ }^{2-4}$ In addition, some derivatives with 
thiosemicarbazone and semicarbazone scaffolds were synthesized and screened to evaluate their ability for interaction with cruzain, and it was revealed that thiosemicarbazones are active against the cysteine protease, indicating that electronic and steric differences between a sulfur and an oxygen atom make a substantial difference to biological activity. ${ }^{5}$

A novel class of anti-infective molecules currently not used clinically is the thiazole peptides. Some 4-thiazolidone derivatives have antibacterial, antituberculosis, antifungal, ${ }^{7}$ and antiparasitic ${ }^{8,9}$ activities, among others. Some thiazole peptides, a family of natural products, are known for their potent antibacterial activity, predominantly resulting from their inhibitory activity on protein synthesis. ${ }^{10}$

During previous studies aiming to discover structures endowed with trypanocidal activity, we synthesized derivatives that possess a thiosemicarbazone or a hydrazine-thiazolidone scaffold. A series of arylthiosemicarbazone or aminoacyl-thiazolidone derivatives were synthesized. Here, we report the synthesis of acyl-hydrazine, thiosemicarbazone, and acyl-thiazolidone and the in vitro evaluation of their ability to inhibit the growth of epimastigote and trypomastigote forms of T. cruzi, as well as a docking analysis under $T$. cruzi cruzain (TCC). The compounds designed were thus analyzed as potential ligands for cruzain.

\section{Chemistry}

\subsection{Synthesis}

Initially we developed three series of peptidyl-thiazolidone and peptidyl-2-methyl-3-thiosemicarbazides. In

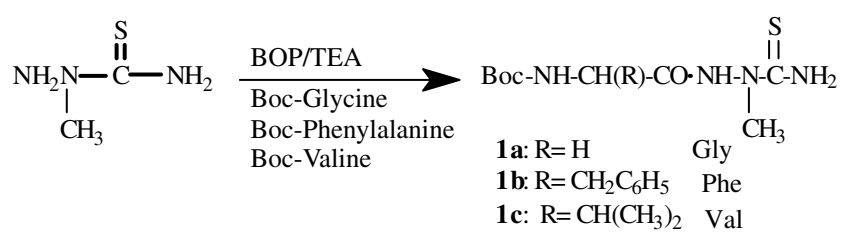

Scheme 1. Synthesis of aminoacyl-thiosemicarbazides. order to obtain the aminoacyl-2-methyl-3-thiosemicabazides, a condensation reaction between 2-methyl-3thiosemicabazide and amino acids (tert-butoxycarbonylglycine, valine, and phenylalanine), BOP Castro's reagent (benzotriazolyloxy-tris-(dimethylamino) phosphonium hexafluorophosphate) was the most efficient carbonyl activant used. Compounds 1a-c were obtained with a yield of $32-46 \%$ (Scheme 1). ${ }^{11}$

To obtain compounds $\mathbf{3}$ and $\mathbf{5 a - c}$ (Scheme 2) we used the symmetrical anhydride (Boc) ${ }_{2} \mathrm{O}$ (di-tert-butylpyrocarbonate) to protect the amine function of thiosemicarbazide. The intermediate compound $\mathbf{2}$ was obtained with a yield of $55 \%$. In the second step, the cyclization was accomplished through the reaction of the Boc-thiosemicarbazide and chloroacetic acid in the presence of sodium acetate, using ethanol as a solvent under reflux to obtain 3 with a yield of $78 \%$. For the removal of the Boc-protecting group of 4-thiazolidone, classical cleavage conditions using TFA/ $\mathrm{CH}_{2} \mathrm{Cl}_{2}$ (1:1) give rise to unprotected 4-thiazolidone 4 ( $98 \%$ yield). The last stage involves condensation of the $\alpha$-amino acids (tert-butyloxycarbonyl-L-phenylalanine, or a tert-butyloxycarbonyl-L-glycine, or tert-butyloxycarbonyl-L-proline) with the amine moiety of the 4-thiazolidone using dicyclohexylcarbodiimide (DCC) and $N$-hydroxysuccinimide $(\mathrm{OH}-\mathrm{Su})$ as carbonyl activating agents. This method resulted in average yields of $68-80 \%{ }^{12,13}$

Compounds 10a,c, and $\mathbf{b}$, were prepared according to two strategies. Different thiophenols were reacted with bromoacetaldehyde diethyl acetal (10a and c) or chloropropanone (10b) in the presence of $\mathrm{KOH} / \mathrm{Cu}$ to produce the corresponding ketone (6) and diethyl acetals (7). After treatment in acid medium, compound 7 produced the aldehyde 8 . Aldehydes and ketones were condensed with thiosemicarbazide to obtain thiosemicarbazones 9 . Cyclization of precursor 9 with chloroacetic acid or $\alpha$ chloropropionic acid generated thiazolidone-hydrazone derivatives (Scheme 3). ${ }^{9}$

\subsection{Molecular modeling}

The structures and conformational analysis of compounds $1,3,5$, and 10 were obtained through the application of the $\mathrm{AM} 1^{14}$ method available as part of the

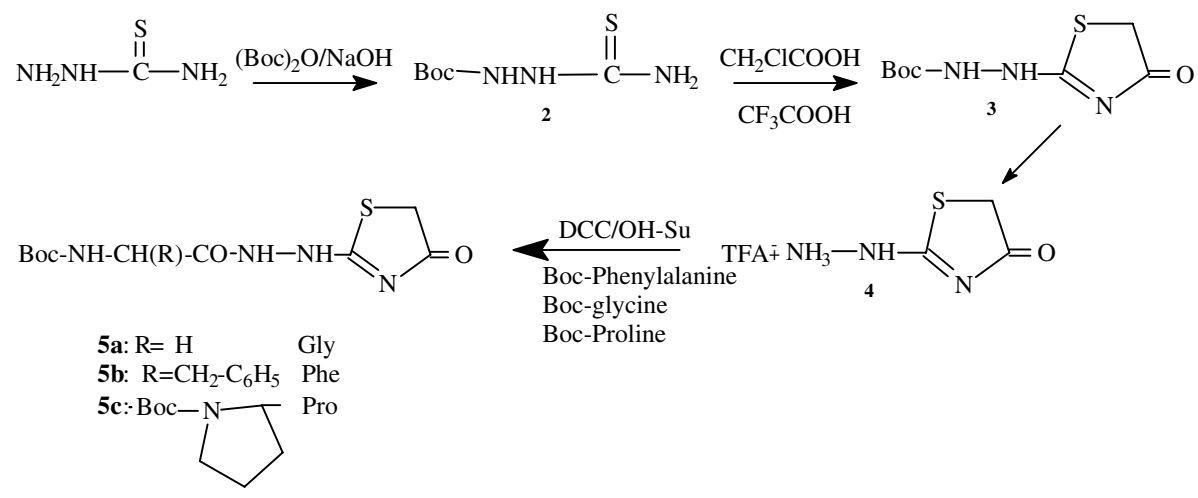

Scheme 2. Synthesis of the aminoacyl-4-thiazolidone derivatives. 




Scheme 3. Synthesis of the 4-thiazolidone-2-arylthiosemicarbazone derivatives.

BioMedCache software package, ${ }^{15}$ using internal default settings for convergence criteria.

Molecules 10a and $\mathbf{b}$ were synthesized and tested as racemic mixtures, so the molecular modeling treats the two enantiomers ( $R$ and $S$ ) independently and the docking procedure uses both isomers for each compound.

The docking analysis was first carried out on the T. cruzi cysteine protease cruzain (TCC) binding site (structure 1U9Q, ${ }^{16}$ taken from the RCSB Protein Data Bank, $<\mathrm{http}: / /$ www.rcsb.org/pdb/>), where the residues are bonded more closely to the ligand known as '186', cocrystallized in complex with cruzain. This crystal structure is present in a monomeric form, with a chain named $\mathrm{X}$, and there is a ligand binding domain. The ' 186 ' ligand was extracted from the complex, and during the calculations the active site was defined to lie within a cube of about $18 \AA$ in each direction, centered on the coordinates $(X=3.357 ; Y=11.064$; and $Z=6.235)$ of the co-crystallized ligand, certainly covering the active site region. Inside this pre-defined region, the grids of probe atom interaction energies were computed at a resolution of $0.20 \AA$ and the ligand probes were then docked using the Genetic Algorithm followed by a Local Search procedure (GA_LS), also known as a Lamarckian Genetic Algorithm (LGA), ${ }^{17}$ and the 50 lowest energy structures were stored for further analysis.

The docking analysis of compounds $\mathbf{1}, \mathbf{3}, \mathbf{5}$, and $\mathbf{1 0}$ was carried out using the AutoDockTools (ADT) v1.1 ${ }^{18}$ and Autodock v3.0.5 ${ }^{19}$ programs, using the default parameters for all the variables, except for the number of docking runs (50), the maximum number of energy evaluations on Genetic Algorithm-GA $(25,000,000)$, and the maximum number of generations in GA $(10,000)$. Preliminary calculations indicate that these three specific parameter modifications provide significant improvement in the results obtained using the docking procedure, thereby producing more stable binding of the ligands. The active site was treated as a rigid molecule, whereas the ligands were treated as flexible, which means that all non-ring torsions were maintained (active).

\section{Pharmacology}

\subsection{Cytotoxicity}

The compounds were tested in different concentrations in mouse spleen cell cultures as described in Section 6 . The highest non-toxic concentration of each compound was then used in subsequent assays to evaluate their anti-T. cruzi activity.

\subsection{Anti-Trypanosoma cruzi activity}

The compounds were tested in vitro against epimastigote ( $\mathrm{Y}$ and Colombian strains) and trypomastigote (Colombian strain) forms of $T$. cruzi at non-cytotoxic concentrations as outlined in Section 6. Table 1 shows the percentage of inhibition for the derivatives under evaluation and the $\mathrm{IC}_{50}$ for $\mathrm{Y}$ strain epimastigotes.

\section{Results and discussion}

In the course of our search for new structures, including an aminoacyl or a hydrazine-hydrazone moiety, a number of synthesis strategies were employed. First, we developed three series of peptidyl-thiazolidone, peptidyl-2-methyl-3-thiosemicarbazide, and thiazolidone-thiosemicarbazone. Ten compounds were identified as active against $T$. cruzi. We observed a thiosemicarbazone and/or hydrazine-4-thiazolidone (Figs. 1a and b) scaffold common to several analogues. The thiosemicarbazone (Fig. 1a) scaffold has been described as possessing useful properties, such as low molecular weight, reasonable $\mathrm{C} \log P$, good hydrogen bonding properties, and easy and economical synthetic routes. ${ }^{5}$

In the present work, the compounds were tested at noncytotoxic concentrations on the epimastigote form of $\mathrm{Y}$ and Colombian strains and the trypomastigote form of Colombian strain. As shown in Table 1, in the case of compounds 1a-c, $\mathbf{1 b}$ (phenylalanine) was the most active against the epimastigote form of $\mathrm{Y}$ and Colombian strains. Compound 1c, in a high concentration, was inactive after the 11th day of treatment. In the case of compounds $\mathbf{3}$ (intermediate) and $\mathbf{5 a - c}$, no decrease in 
Table 1. Biological properties of compounds

\begin{tabular}{|c|c|c|c|c|c|}
\hline \multirow[t]{3}{*}{ Compound } & \multicolumn{5}{|c|}{ Percentage of growth inhibition ${ }^{\mathrm{c}}(\%)$} \\
\hline & \multirow{2}{*}{$\begin{array}{l}\text { Concentration } \\
(\mu \mathrm{mol} / \mathrm{L})^{\mathrm{a}}\end{array}$} & \multicolumn{2}{|c|}{ Y Epimastigote } & \multirow{2}{*}{$\begin{array}{l}\text { Colombian } \\
\text { epimastigote } \\
\text { at } 11 \text { days }\end{array}$} & \multirow{2}{*}{$\begin{array}{l}\text { Colombian } \\
\text { trypomastigote } \\
\text { at } 24 \mathrm{~h}\end{array}$} \\
\hline & & $11^{\circ}$ day & $\overline{\mathrm{IC}_{50}{ }^{\mathrm{b}}}$ & & \\
\hline $1 \mathbf{a}$ & 38.1 & 50.0 & 114.4 & 50.0 & 5.4 \\
\hline 1b & 283.7 & 92.3 & 85.1 & 95.0 & 8.1 \\
\hline $1 c$ & 328.5 & 7.0 & 495.7 & 50.0 & 5.4 \\
\hline 3 & 4.3 & 52.2 & 142.6 & 55.6 & 44.0 \\
\hline $\mathbf{5 a}$ & 3.4 & 0.0 & 73.4 & 11.1 & 48.0 \\
\hline $5 \mathbf{b}$ & 2.6 & 8.7 & 83.3 & 55.6 & 36.0 \\
\hline $5 \mathrm{c}$ & 30.4 & 65.2 & 30.5 & 0.0 & 12.0 \\
\hline $10 \mathrm{a}$ & 31.8 & 89.0 & 31.9 & 20.0 & 27.0 \\
\hline $10 \mathrm{~b}$ & 340.8 & 100.0 & 128.4 & 60.0 & 75.7 \\
\hline $10 \mathrm{c}$ & 35.8 & 92.3 & 45.0 & 50.0 & 21.6 \\
\hline $\mathrm{Bz}^{\mathrm{d}}$ & 38.2 & 99.7 & 1.8 & 77.8 & 100.0 \\
\hline
\end{tabular}

${ }^{a}$ Determined by cytotoxicity assay using mouse splenocytes.

${ }^{\mathrm{b}} \mu \mathrm{mol} / \mathrm{L}$.

${ }^{\mathrm{c}}$ Percentage of growth inhibition calculated as described in Section 3.1.

${ }^{\mathrm{d}} \mathrm{Bz}$, Benznidazole.<smiles>NNC1=NC(=O)CS1</smiles>

Figure 1. Thiosemicarbazone and thiazolidone scaffold.

cytotoxicity was observed, indicating that the use of the aminoacyl moiety in the thiazolidone scaffold has no effect on cytotoxicity. Only compound 5c (a proline derivative) was five times more active than intermediate $\mathbf{3}$, and about twice as active as $\mathbf{5 a}$ and $\mathbf{b}$. However, this compound was inactive against the Colombian strain. With regard to the aryl-thiazolin-hydrazone series (compounds 10a-c), biological analyses revealed that 10b (in racemic form) was the least cytotoxic and the most active against the Colombian strain in a high concentration. Compound 10a (in racemic form) was the most active at the concentrations tested. This compound possesses a chlorine substituent in the phenyl ring system and has shown itself to be active against epimastigote, in comparison with benznidazole. In general, this series showed good trypanocidal activity. In accordance with previous works, our results confirm the importance of the thiosemicarbazone scaffold for trypanocidal activity. $^{5}$

The most stable docking solutions for the complexes between compounds $\mathbf{1}, \mathbf{3}, \mathbf{5}$, and $\mathbf{1 0}$ and TCC are presented in Table 2, along with the free energy of binding $(\Delta G)$ values. In order to investigate possible correlations between experimental and theoretical data, the free energy of binding $(\mathrm{kcal} / \mathrm{mol})$ was plotted against the $\mathrm{pIC}_{50}$ (equals $-\log \mathrm{IC}_{50}$ of the $\mathrm{Y}$ strain epimastigotes) values. The $\mathrm{pIC}_{50}$ and free energy of binding values are presented in Table 2 and plotted in Figure 2.

Figure 2 provides evidence of a correlation between theoretical binding (docking) and the $\mathrm{IC}_{50}$ data, that is, the most active molecules or the compounds that have high-
Table 2. Docking results for compounds $\mathbf{1 , 3}, \mathbf{5}$, and $\mathbf{1 0}$

\begin{tabular}{lll}
\hline Compound & $\begin{array}{l}\mathrm{pIC}_{50}=-\log \mathrm{IC}_{50} \\
\left(\text { with } \mathrm{IC}_{50} \text { in } \mathrm{mol} / \mathrm{L}\right)\end{array}$ & $\begin{array}{l}\text { Free energy of binding } \\
(\mathrm{kcal} / \mathrm{mol})\end{array}$ \\
\hline $\mathbf{1 a}$ & 3.94 & -5.48 \\
$\mathbf{1 b}$ & 4.07 & -6.27 \\
$\mathbf{1 c}$ & 3.30 & -5.67 \\
$\mathbf{3}$ & 3.85 & -5.36 \\
$\mathbf{5 a}$ & 4.13 & -5.27 \\
$\mathbf{5 b}$ & 4.08 & -6.88 \\
$\mathbf{5 c}$ & 4.52 & -7.01 \\
$\mathbf{1 0 a}$ & 4.50 & $-6.92(R)$ and $-7.10(S)$ \\
$\mathbf{1 0 b}$ & 3.89 & $-7.02(R)$ and $-7.01(S)$ \\
$\mathbf{1 0 c}$ & 4.35 & -6.67 \\
\hline
\end{tabular}

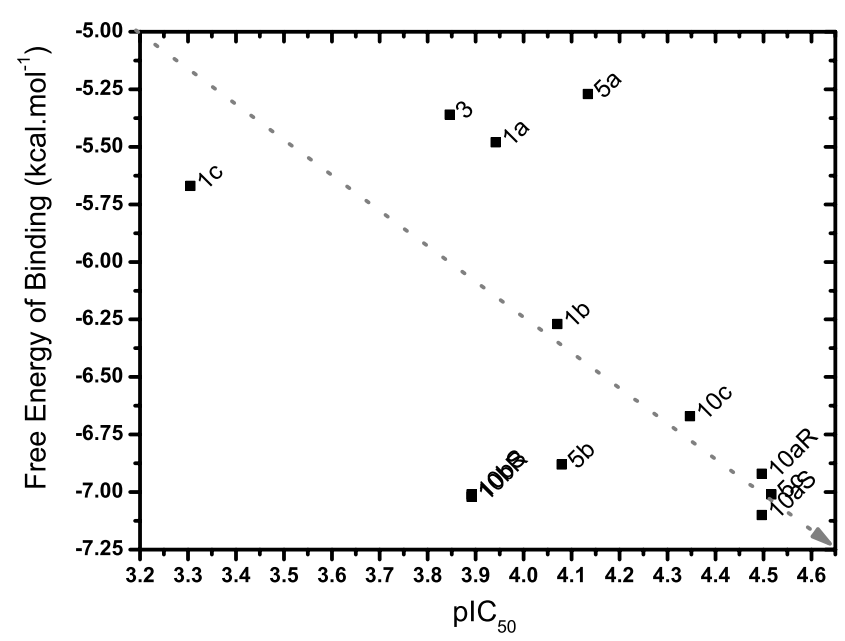

Figure 2. Correlation between the free energy of binding (kcal/mol) and the $\mathrm{pIC}_{50}$ (equals $-\log \mathrm{IC}_{50}$ ) values for molecules $\mathbf{1}, \mathbf{3}, \mathbf{5}$, and $\mathbf{1 0}$. For molecules 10a and $\mathbf{b}$ were used the both enantiomers, $R$ and $S$. The stippled line at the diagonal is only for visualization purposes, in order to make easier the identification of the correlation between the variables.

er values for $\mathrm{pIC}_{50}$, are those with most negative free energy of binding, showing that the molecules with more stable or negative binding energies are also the most 
active (greater affinity for TCC), at least when the $\mathrm{Y}$ strain is considered.

In order to compare the binding pattern of these molecules, the compound that produced the best result (i.e., the most stable complex) in docking analysis-the $S$ enantiomer of molecule 10a was analyzed, along with the crystallographic structure of TCC, and the results of this comparison can be seen in Figure 3.

Figure 3 shows that compound 10a ( $S$ enantiomer) (ball and stick model) establishes hydrogen bonds with the GLY66, MET68, and ASN69 residues of the TCC binding site (colored line model with three letter codes in yellow), with 2.258, 1.894 and $2.078 \AA$ measured distances, respectively. It should be pointed out that the ligand '186', co-crystallized with TCC in the structure 1U9Q, also shows an important hydrogen bond with the residue GLY66, in the same ligand binding domain.

Figure 4 illustrates the important interactions between the 10a ( $S$ enantiomer) compound and the TCC, after docking studies, in similar a fashion to Figure 3. These interactions include three important hydrogen bonds (as in Fig. 3) and also hydrophobic interactions between ligand and target residues. The LIGPLOT program ${ }^{20}$ was used to produce Figure 4.

For comparison reasons, one can see in Figure 5 the crystallographic structure of the ligand named ' 186 ' at the binding site of TCC, in order to understand the selection of this ligand-interaction site.

\section{Conclusion}

New thiosemicarbazones, aminoacyl-thiosemicarbazides, and aminoacyl-thiazolidones were synthesized using accessible methodologies. Some derivatives exhibit significant in vitro activity against epimastigote $T$. cruzi, particularly compounds $\mathbf{5 c}$ and $\mathbf{1 0 a}$. The docking results corroborate the experimental $\mathrm{IC}_{50}$ data, and a detailed analysis of the binding characteristics of these ligands in TCC reveals important and specific interactions, which are important for describing the affinity of such molecules to the cruzain. These results confirm that the thiosemicarbazone scaffold is a potential anti-T. $\mathrm{cru}$ $z i$ agent. Additional structural optimization, in vivo activity studies and the characterization of the pharmacokinetics of these compounds are currently underway.

\section{Experimental}

\subsection{Chemistry}

All melting points were determined using a Thomas Hoover apparatus and are uncorrected. IR spectra were obtained using $\mathrm{KBr}$ pellets. ${ }^{1} \mathrm{H}$ and ${ }^{13} \mathrm{C}$ NMR spectra were measured using a Varian UNITYplus-300 MHz NMR spectrophotometer using DMSO- $d_{6}$ as solvent and tetramethylsilane as an internal standard. Thinlayer chromatography (TLC) was carried out on silica gel plates with a fluorescence indicator of $F_{254}$ $(0.2 \mathrm{~mm}$, E. Merck); the spots were visualized in UV light and by spraying with a $2 \%$ ethanol solution of ninhydrin or charing reagent. Column chromatography was performed on silica using Kieselgel 60 (230400 mesh, E. Merck). All reagents used in the present study were of analytical grade.

6.1.1. General procedure for compounds 1a-c. The Nprotected amino acid $(1 \mathrm{mmol})$ was dissolved in DMF (10 mL) containing $1 \mathrm{mmol}$ of 2-methyl-3-thiosemicarbazide and BOP (1 mmol). The solution was cooled in an ice bath, and TEA $(0.7 \mathrm{~mL})$ was added to it. The preparation was left to stand for $12 \mathrm{~h}$ at room temperature. Then, dichloromethane $(50 \mathrm{~mL})$ was added under stirring. The organic layer was washed several times with sodium bicarbonate $(50 \mathrm{~mL})$, water $(50 \mathrm{~mL}), 1 \mathrm{M}$ citric acid $(50 \mathrm{~mL})$, water $(50 \mathrm{~mL})$, dried over sodium sulfate, and concentrated in vacuo. The residue was purified using silica gel column chromatography, with ethyl acetate-hexane $(1: 1)$ as a solvent, and produced a white powder when crystallized with diethyl etherhexane.

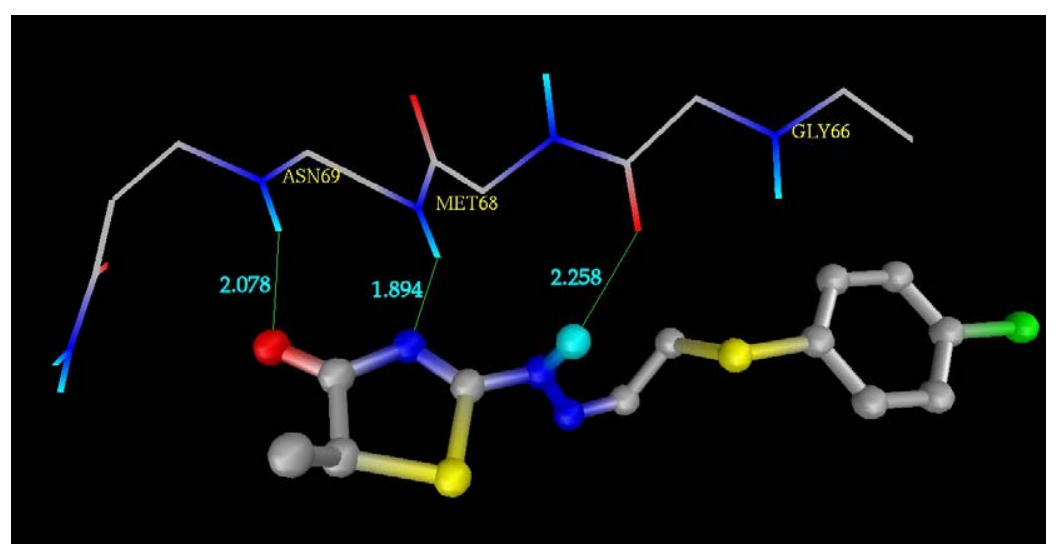

Figure 3. Important hydrogen bonds between the $S$ enantiomer of compound 10a (ball and stick model) and residues (colored line model with three letter codes in yellow) of the TCC structure, obtained by the docking procedure. The distances for hydrogen bonding are given in angstrom and are labeled in blue. The rest of the protein structure was suppressed for clarification purposes. 

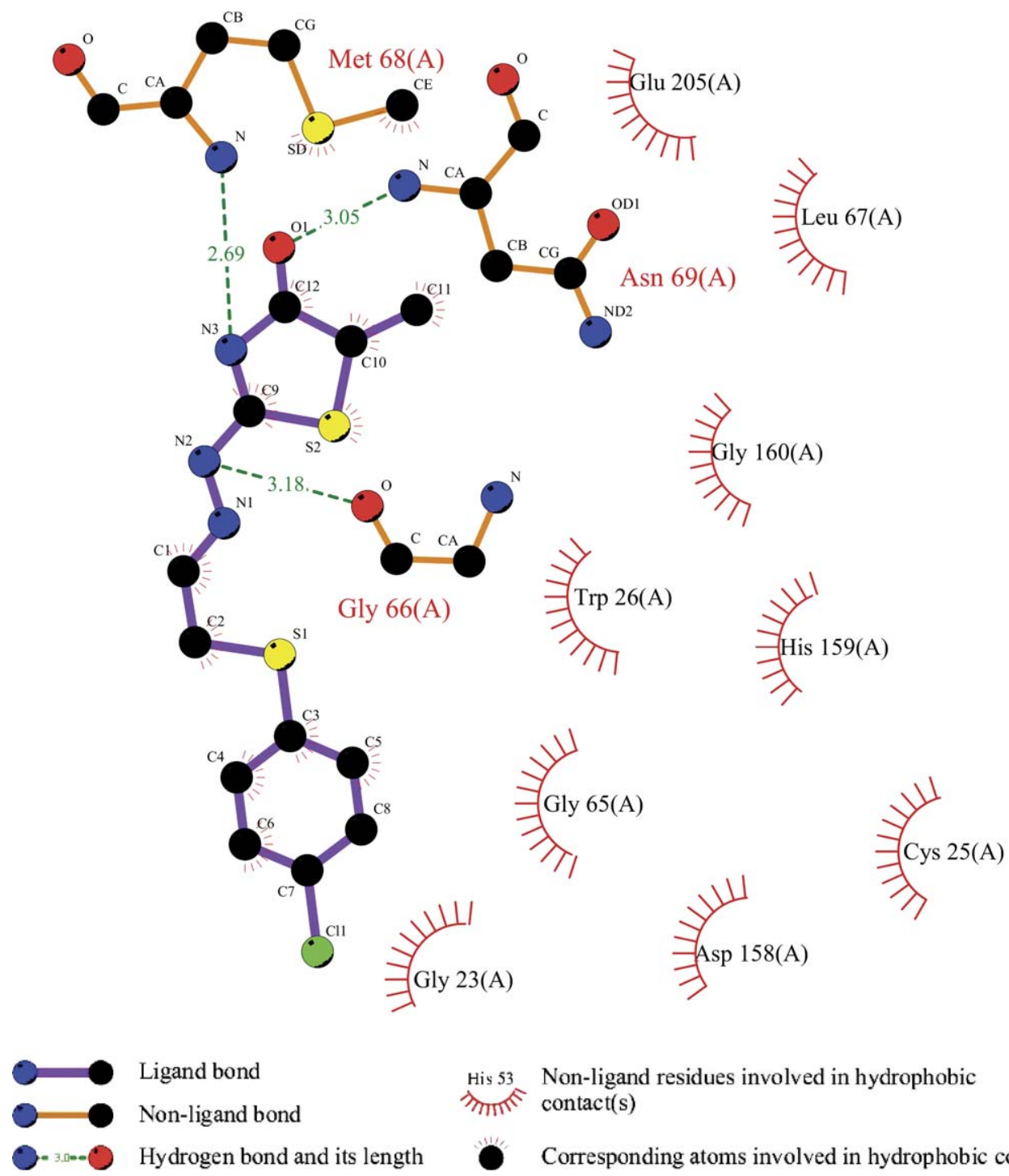

Ligand bond

Non-ligand bond

His 53 Non-ligand residues involved in hydrophobic

$\lambda_{\pi, \pi}$ contact(s)

Hydrogen bond and its length

Corresponding atoms involved in hydrophobic contact(s)

Figure 4. Schematic figure of the important interactions between the 10a ( $S$ enantiomer) compound and the TCC, including hydrogen bonds and hydrophobic interactions with specific residues. The legend for this figure is presented on the bottom.

6.1.1.1. 1-[2-(tert-Butoxycarbonyl)aminoacetyl]-2methylthiosemicarbazide (1a). Yield: $42 \%$; mp $92-4{ }^{\circ} \mathrm{C}$; $R_{\mathrm{f}}=0.62$ (ethyl acetate); IR $\left(\mathrm{KBr} / \mathrm{cm}^{-1}\right): 1087,1243$, 1311, 1625, 2928, 3035, 3326; ${ }^{1} \mathrm{H}$ NMR (DMSO- $d_{6} /$ ppm) $\delta: 1.36\left(\mathrm{~s}, 9 \mathrm{H},\left(\mathrm{CH}_{3}\right)_{3}\right), 1.54(\mathrm{t}, J=7.4,3 \mathrm{H}$, $\left.\mathrm{CH}_{\beta}\right), 3.35\left(\mathrm{~s}, 3 \mathrm{H}, \mathrm{N}_{2}-\mathrm{CH}_{3}\right), 4.30\left(\mathrm{~s}, 2 \mathrm{H}, \mathrm{NH}_{2}\right), 5.03$ $\left(\mathrm{d}, J=5.9,2 \mathrm{H}, \mathrm{CH}_{\alpha}\right), 7.38\left(\mathrm{t}, J=5.9,1 \mathrm{H}, \mathrm{NH}_{\alpha}\right), 8.24$ $\left(\mathrm{d}, J=8.3,1 \mathrm{H}, \mathrm{N}_{2}-\mathrm{H}\right), 9.40\left(\mathrm{~s}, 1 \mathrm{H}, \mathrm{N}_{1}-\mathrm{H}\right) ;{ }^{13} \mathrm{C}$ NMR (DMSO- $\left.d_{6} / \mathrm{ppm}\right) \delta$ : 28.36, 35.65, 46.01, 78.96, 158.08, 162.52, 169.88; $\mathrm{C}_{11} \mathrm{H}_{14} \mathrm{~N}_{4} \mathrm{O}_{3} \mathrm{~S}$.

6.1.1.2. 1-[2-(tert-Butoxycarbonyl)-2-benzyl-aminoacetyl]-2-methylthiosemicarbazide (1b). Yield: 79\%; mp $102-3{ }^{\circ} \mathrm{C} ; \quad R_{\mathrm{f}}=0.68$ (ethyl acetate); IR $\left(\mathrm{KBr} / \mathrm{cm}^{-1}\right)$ : $1114,1245,1416,1668,2941,2995,3332 ;{ }^{1} \mathrm{H}$ NMR $\left(\mathrm{DMSO}-d_{6} / \mathrm{ppm}\right) \delta: 1.23-1.32\left(\mathrm{~s}, 9 \mathrm{H},\left(\mathrm{CH}_{3}\right)_{3}\right), 2.50$ $\left(\mathrm{t}, J=8.7,2 \mathrm{H}, \mathrm{CH}_{\beta}\right), 3.35\left(\mathrm{~s}, 3 \mathrm{H}, \mathrm{N}_{2}-\mathrm{CH}_{3}\right), 4.30(\mathrm{~s}$, $\left.2 \mathrm{H}, \mathrm{NH}_{2}\right), 4.48-7.43-7.48(\mathrm{~m}, 5 \mathrm{H}, \mathrm{Ar}), 4.56(1 \mathrm{H}$, $\left.\mathrm{CH}_{\alpha}\right), 6.92\left(\mathrm{~d}, J=7.1,1 \mathrm{H}, \mathrm{NH}_{\alpha}\right), 8.80(\mathrm{~d}, J=8.3$, $\left.1 \mathrm{H}, \mathrm{N}_{2}-\mathrm{H}\right), 9.35\left(\mathrm{~s}, 1 \mathrm{H}, \mathrm{N}_{1}-\mathrm{H}\right)$; ${ }^{13} \mathrm{C}$ NMR (DMSO$\left.d_{6} / \mathrm{ppm}\right) \delta: 28.48,38.48,46.08,56.75,79.25,124.36$,
$128.32, \quad 128.71, \quad 137.23, \quad 156.08, \quad 169.63, \quad 170.63$ $\mathrm{C}_{16} \mathrm{H}_{24} \mathrm{~N}_{4} \mathrm{O}_{3} \mathrm{~S}$.

6.1.1.3. 1-[2-(tert-Butoxycarbonyl)-2-isopropyl-aminoacetyl]-2-methylthiosemicarbazide (1c). Yield: 74\%; mp $134-6{ }^{\circ} \mathrm{C} ; \quad R_{\mathrm{f}}=0.57$ (ethyl acetate); IR $\left(\mathrm{KBr} / \mathrm{cm}^{-1}\right)$ : 1044, 1203, 1511, 1668, 2973, 3204, 3304; ${ }^{1} \mathrm{H}$ NMR (DMSO- $\left.d_{6} / \mathrm{ppm}\right) \delta: 1.59\left(\mathrm{~s}, 9 \mathrm{H},\left(\mathrm{CH}_{3}\right)_{3}\right), 2.42(\mathrm{~s}, 3 \mathrm{H}$, $\left.\mathrm{N}_{2}-\mathrm{CH}_{3}\right), 2.50\left(\mathrm{t}, J=8.7,2 \mathrm{HCH}_{\beta}\right), 4.30(\mathrm{~s}, 2 \mathrm{H}$, $\left.\mathrm{NH}_{2}\right), 4.48-4.56\left(1 \mathrm{H}, \mathrm{CH}_{\alpha}\right), 7.95\left(\mathrm{~s}, 1 \mathrm{H}, \mathrm{NH}_{\alpha}\right), 9.85$ $\left(\mathrm{s}, 1 \mathrm{H}, \mathrm{N}_{1}-\mathrm{H}\right) ;{ }^{13} \mathrm{C}$ NMR (DMSO- $\left.d_{6} / \mathrm{ppm}\right) \delta: 18.96$, 28.21，28.79, 36.98, 78.81, 156.54, 170.32, 182.15; $\mathrm{C}_{12} \mathrm{H}_{24} \mathrm{~N}_{4} \mathrm{O}_{3} \mathrm{~S}$.

6.1.2. General procedure for compounds 2 and $5 a-c$. 6.1.2.1. 1-[tert-Butyloxycarbonyl]thiosemicarbazide (2). A solution of thiosemicarbazide $(1 \mathrm{mmol})$, dioxane $(20 \mathrm{~mL})$, water $(10 \mathrm{~mL})$, and $1 \mathrm{~N} \mathrm{NaOH}(11 \mathrm{~mL})$ was stirred in an ice-water bath. Di-tert-butyl pyrocarbonate $(2.4 \mathrm{~g}, 11 \mathrm{mmol})$ was added and stirring was continued at room temperature for $30 \mathrm{~min}$. The solution was con- 


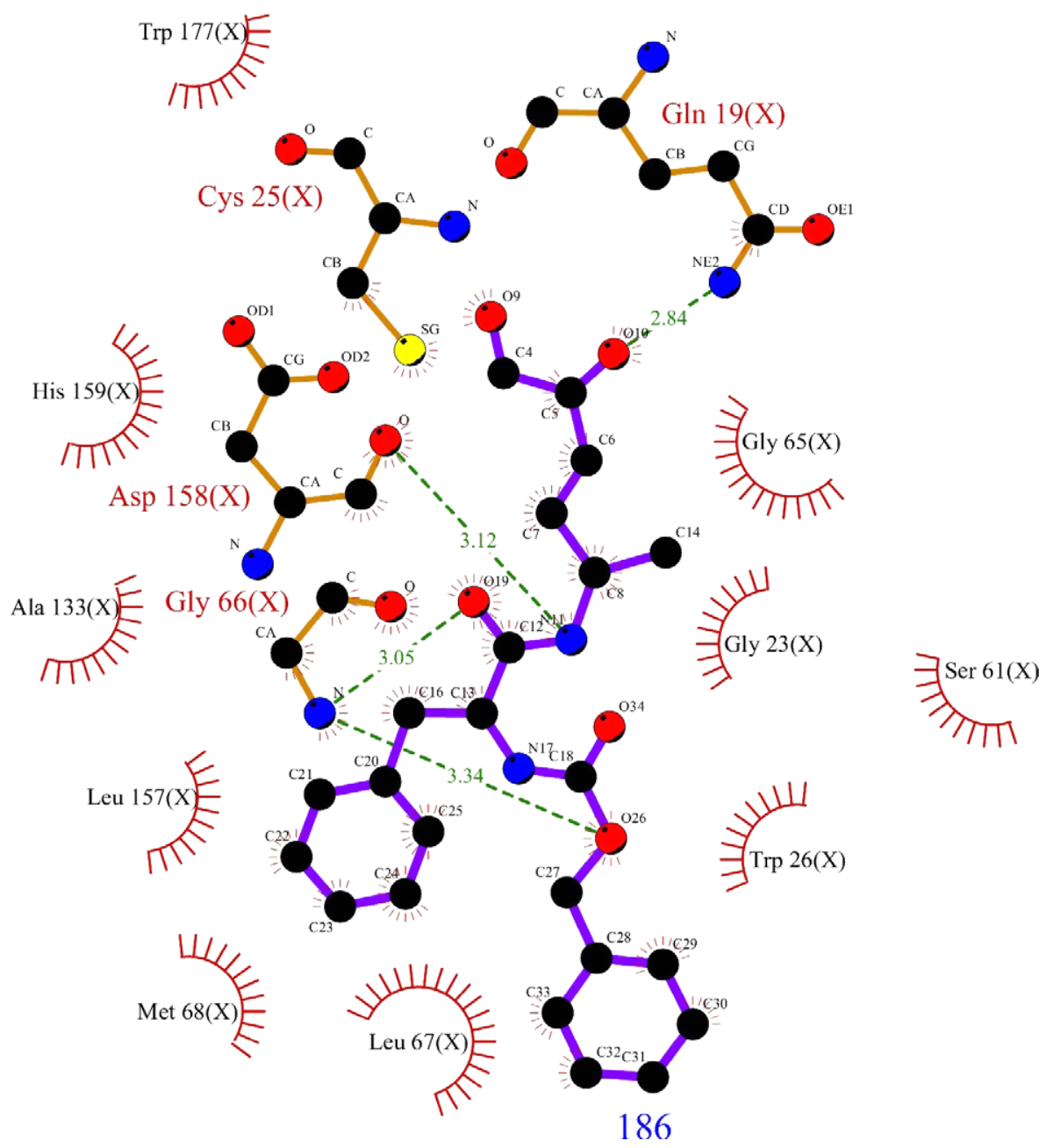

Figure 5. Schematic figure of the crystallographic structure of ligand named ' 186 ' into TCC, including hydrogen bonds and hydrophobic interactions with specific residues. The legend for this figure is presented in Figure 4.

centrated in vacuo to about $10-15 \mathrm{~mL}$, cooled in an icewater bath, covered with a layer of ethyl acetate $(30 \mathrm{~mL})$, and acidified with a dilute solution of $\mathrm{KHSO}_{4}$ to $\mathrm{pH} 2-3$ (Congo paper). The aqueous phase was extracted using ethyl acetate $(15 \mathrm{~mL})$ and the extraction repeated. The ethyl acetate extracts were pooled, washed with water (twice, $30 \mathrm{~mL}$ each time) dried over anhydrous $\mathrm{Na}_{2} \mathrm{SO}_{4}$, and evaporated it in vacuo.

Yield: $37 \% ; \mathrm{mp} 170-2, R_{\mathrm{f}}=0.72$ (ethyl acetate), IR $\left(\mathrm{KBr} / \mathrm{cm}^{-1}\right): 1052,1285,1720,3189,3375 ;{ }^{1} \mathrm{H}$ NMR $\left(\mathrm{DMSO}-d_{6} / \mathrm{ppm}\right) \delta: 1.45\left(\mathrm{~m}, 9 \mathrm{H},\left(\mathrm{CH}_{3}\right)_{3}\right), 7.32(\mathrm{~s}, 2 \mathrm{H}$, $\left.\mathrm{NH}_{2}\right), 7.75(\mathrm{~s}, 1 \mathrm{H}, \mathrm{N}-\mathrm{H}), 8.78(\mathrm{~s}, 1 \mathrm{H}, \mathrm{N}-\mathrm{H})$.

6.1.2.2. 1-(tert-Butyloxycarbonylamino)-2-(4-oxo-4,5dihydrothiazol-2-yl)hydrazide (3). The mixture of protected thiosemicarbazide ( $2 \mathrm{mmol}), \alpha$-chloroacetic acid, and sodium acetate $(2 \mathrm{mmol})$ in ethanol $(10 \mathrm{~mL})$ was stirred for $6 \mathrm{~h}$ at reflux temperature. When the reaction had been completed, the mixture was left at $-4{ }^{\circ} \mathrm{C}$ for $72 \mathrm{~h}$. Then, hexane was added and the solid was filtered. Ethyl acetate was added and the organic phase was washed with water, dried (over anhydrous sodium sulfate), and evaporated. The Boc-hydrazino-4-thiazolidone intermediate (3) was treated with a mixture of trifluoroacetic acid and dichloromethane $(10 \mathrm{~mL})$ to obtain the deprotected hydrazino-4-thiazolidone (4). The $\mathrm{N}$-protected amino acid in dimethylformamide under $0{ }^{\circ} \mathrm{C}, \quad 6.8 \mathrm{mmol}$ of the dicyclohexylcarbodiimide, $5.1 \mathrm{mmol}$ of $N$-hydroxysuccinimide, and $1.7 \mathrm{mmol}$ of intermediate 4 was added and was allowed to warm to room temperature. Subsequently, the reaction mixture was filtered, and the filtrate was treated with ethyl acetate. The organic phase was washed with $\mathrm{NaHCO}_{3}$, water and aqueous $\mathrm{NaCl}$, dried over $\mathrm{Na}_{2} \mathrm{SO}_{4}$ solution, and concentrated. The residue was treated with hexane and filtered.

Yield: 76\%; mp 165-7, $R_{\mathrm{f}}=0.68$ (7:3, ethyl acetate/hexane), IR $\left(\mathrm{KBr} / \mathrm{cm}^{-1}\right): 1250,1456,1717,3135 ;{ }^{1} \mathrm{H}$ NMR $\left(\mathrm{DMSO}-d_{6} / \mathrm{ppm}\right) \delta: 1.47\left(\mathrm{~m}, 9 \mathrm{H},\left(\mathrm{CH}_{3}\right)_{3}\right), 3.93(2 \mathrm{H}$, $\left.\mathrm{CH}_{2}\right), 9.39(\mathrm{~s}, 1 \mathrm{H}, \mathrm{N}-\mathrm{H}), 11.30(\mathrm{~s}, 1 \mathrm{H}, \mathrm{N}-\mathrm{H}) ;{ }^{13} \mathrm{C}$ NMR (DMSO- $\left.d_{6} / \mathrm{ppm}\right) \delta: 27.76,31.85,76.85,155.23$, 167.92, 173.98; $\mathrm{C}_{8} \mathrm{H}_{13} \mathrm{~N}_{3} \mathrm{O}_{3} \mathrm{~S}$.

6.1.2.3. 2-(4-Oxo-4,5-dihydrothiazol-2-yl)-1-(2-[tertbutoxycarbonylaminolethane)hydrazide (5a). Yield: $68 \% ; \mathrm{mp} 152-4{ }^{\circ} \mathrm{C}, R_{\mathrm{f}}=0.6$ (7:3, ethyl acetate/hexane), IR $\left(\mathrm{KBr} / \mathrm{cm}^{-1}\right): 1244,1536,1710,3328 ;{ }^{1} \mathrm{H}$ NMR $\left(\mathrm{DMSO}-d_{6} / \mathrm{ppm}\right): 1.24\left(\mathrm{~s}, 9 \mathrm{H},\left(\mathrm{CH}_{3}\right)_{3}\right), 2.41(\mathrm{~s}, 2 \mathrm{H}$, 
$\left.\mathrm{CH}_{2}\right), \quad 3.66\left(\mathrm{dd}, \quad J=6.2 \mathrm{~Hz}, \quad 2 \mathrm{H} \quad \mathrm{CH}_{\alpha}\right), \quad 5.55 \quad(\mathrm{~d}$, $J=7.7 \mathrm{~Hz}, 1 \mathrm{H}, \mathrm{NH}), 7.48\left(\mathrm{t}, J=6.2 \mathrm{~Hz}, 1 \mathrm{H}, \mathrm{NH}_{\alpha}\right)$; ${ }^{13} \mathrm{C}$ NMR (DMSO- $\left.d_{6} / \mathrm{ppm}\right) \quad \delta: 27.99,31.45,45.25$, $55.79,80.20,125.39,128.56,144.31,156.14,170.02$, $170.92,175.92 ; \mathrm{C}_{17} \mathrm{H}_{22} \quad \mathrm{~N}_{4} \mathrm{O}_{4} \mathrm{~S}$.

6.1.2.4. 2-(4-Oxo-4,5-dihydrothiazol-2-yl)-1-(2(S)N[tert-butoxycarbonylamino]-3-(phenyl)propane)hydrazide (5b). Yield: $98 \% ; \mathrm{mp} 159-60^{\circ} \mathrm{C}, R_{\mathrm{f}}=0.76$ (7:3, ethyl acetate/hexane), IR $\left(\mathrm{KBr} / \mathrm{cm}^{-1}\right): 1245,1574,1736$, $3329 ;{ }^{1} \mathrm{H}$ NMR (DMSO- $\left.d_{6} / \mathrm{ppm}\right) \delta: 1.24-1.32(\mathrm{~s}, 9 \mathrm{H}$, $\left.\left(\mathrm{CH}_{3}\right)_{3}\right), 1.73\left(\mathrm{~d}, J=10.49 \mathrm{~Hz}, 2 \mathrm{H}, \mathrm{CH}_{\beta}\right), 2.83(\mathrm{~s}, 2 \mathrm{H}$, $\left.\mathrm{CH}_{2}\right), 5.61(\mathrm{~d}, J=7.4 \mathrm{~Hz}, 1 \mathrm{H}, \mathrm{NH}), 4.60-4.50(\mathrm{~m}, 1 \mathrm{H}$ $\mathrm{CH}_{\alpha}$ ), 7.33-7.26 (m, 5H, Ar); ${ }^{13} \mathrm{C}$ NMR (DMSO-d $d_{6}$ ppm) $\delta: 28.39,31.95,41.20,77.52,149.53,158.56$, $170.64,170.86,178.32 ; \mathrm{C}_{13} \mathrm{H}_{20} \mathrm{O}_{4} \mathrm{~N}_{4} \mathrm{~S}$.

6.1.2.5. 2-(4-Oxo-4,5-dihydrothiazol-2-yl)-1-(2(S)N[tert-butoxycarbonylamino]-2-pyrrolidine)hydrazide (5c). Yield: $74 \% ; \mathrm{mp} 105-4{ }^{\circ} \mathrm{C}, R_{\mathrm{f}}=0.64$ (7:3, ethyl acetate/ hexane), IR $\left(\mathrm{KBr} / \mathrm{cm}^{-1}\right)$ : 1132, 1574, 1699, 3328; ${ }^{1} \mathrm{H}$ NMR (DMSO- $\left.d_{6} / \mathrm{ppm}\right): 1.37-1.40\left(\mathrm{~s}, 9 \mathrm{H},\left(\mathrm{CH}_{3}\right)_{3}\right)$, 1.83-1.91 (m, $\left.2 \mathrm{H}, \mathrm{CH}_{\beta}\right), 2.02-2.07\left(\mathrm{~m}, 2 \mathrm{H}, \mathrm{CH}_{\gamma}\right), 2.50$ $\left(\mathrm{t}, J=3.2 \mathrm{~Hz}, 2 \mathrm{H}, \mathrm{CH}_{\delta}\right), 2.81\left(\mathrm{~s}, 2 \mathrm{H}, \mathrm{CH}_{2}\right), 4.57$ (dd, $\left.J=3.5 \mathrm{~Hz}, 3.89,1 \mathrm{H}, \mathrm{CH}_{\alpha}\right), 5.58(\mathrm{~d}, J=7.1 \mathrm{~Hz}, 1 \mathrm{H}$, $\mathrm{NH}) ;{ }^{13} \mathrm{C}$ NMR (DMSO- $\left.d_{6} / \mathrm{ppm}\right) \quad \delta: 24.49,28.33$, $30.25,33.37,45.32,61.72,80.01,154.51,168.49$, 171.01, 175.79; $\mathrm{C}_{13} \mathrm{H}_{20} \mathrm{O}_{4} \mathrm{~N}_{4} \mathrm{~S}$.

6.1.3. General procedure for compounds 10a-c. Thiophenols were reacted with bromoacetaldehyde diethyl acetal $(20 \mathrm{mmol})$ or choro-2-propanone $(20 \mathrm{mmol})$ in the presence of $\mathrm{KOH}(20 \mathrm{mmol})$ and $\mathrm{Cu}(20 \mathrm{mmol})$ to produce the corresponding diethyl acetals and ketones. The diethyl acetals were then refluxed with $2 \mathrm{~N} \mathrm{H}_{2} \mathrm{SO}_{4}$, thereby producing aldehydes. The aldehydes and ketones $(15 \mathrm{mmol})$ were condensed to 2-methyl-3-thiosemicarbazide $(15 \mathrm{mmol})$ in glacial acetic medium $(20 \mathrm{~mL})$ to produce the thiosemicarbazone intermediate. Cyclization of these intermediates with $\alpha$-chloropropionic $(5 \mathrm{mmol})$ acid in the presence of sodium acetate ( $5 \mathrm{mmol}$ ) generated cyclized 4-thiazolidone derivatives with a yield of $30 \%$ and $67 \%$.

6.1.3.1. $N$-(4-Oxo-5-methyl-2-thiazolin-2yl)- $N^{\prime}-p$-chlorophenylthioethylidenehydrazone (10a). Yield: $67 \%$; mp $146-7{ }^{\circ} \mathrm{C}$, recrystallizing solvent: ethanol $(95 \%) / \mathrm{H}_{2} \mathrm{O}$. IR $\left(\mathrm{KBr} / \mathrm{cm}^{-1}\right): 1600,1640,1720,2990 ;{ }^{1} \mathrm{H}$ NMR $\left(\mathrm{DMSO}-d_{6} / \mathrm{ppm}\right): 1.50\left(\mathrm{~d}, J=12 \mathrm{~Hz}, 3 \mathrm{H}, \mathrm{CH}_{3}\right), 3.90$ $\left(\mathrm{d}, J=10.8 \mathrm{~Hz} 2 \mathrm{H}, \mathrm{CH}_{2}\right), 4.20(\mathrm{~m}, 1 \mathrm{H}, \mathrm{CH}), 7.44(\mathrm{~m}$, $4 \mathrm{H}, \mathrm{Ar}), 7.70(\mathrm{t}, \quad J=12 \mathrm{~Hz}, 1 \mathrm{H}, \mathrm{CH}) ;{ }^{13} \mathrm{C} \mathrm{NMR}$ (DMSO- $\left.d_{6} / \mathrm{ppm}\right) \delta: 20.85,35.29,40.52,129.12,129.54$, 144.26, 159.02, 175.20; $\mathrm{C}_{12} \mathrm{H}_{12} \mathrm{ON}_{3} \mathrm{~S}_{2} \mathrm{Cl}$.

6.1.3.2. $\quad N$-(4-Oxo-5-methyl-2-thiazolin-2yl)- $N^{\prime}$-phenylthio-2-propylidenehydrazone (10b). Yield: 44\%; mp $138-9{ }^{\circ} \mathrm{C}$, recrystallizing solvent: absolute ethanol. IR $\left(\mathrm{KBr} / \mathrm{cm}^{-1}\right): \quad 1590, \quad 1645, \quad 1725, \quad 3090 ;{ }^{1} \mathrm{H} \quad \mathrm{NMR}$ (DMSO- $\left.d_{6} / \mathrm{ppm}\right): 1.23\left(\mathrm{~d}, J=7.2 \mathrm{~Hz} 3 \mathrm{H}, \mathrm{CH}_{3}\right), 1.70$ (d, $\left.3 \mathrm{H}, \mathrm{CH}_{3}\right), 3.63\left(\mathrm{~d}, J=7.8 \mathrm{~Hz} 2 \mathrm{H}, \mathrm{CH}_{2}\right), 3.93(\mathrm{~m}$, $1 \mathrm{H}, \mathrm{CH}), 7.20\left(\mathrm{~m}, 5 \mathrm{H}\right.$, aromatic); ${ }^{13} \mathrm{C}$ NMR (DMSO$\left.d_{6} / \mathrm{ppm}\right) \delta: 20.57,34.25,39.50,128.87,129.16,130.97$, 135.81, 155.87, 174.20; $\mathrm{C}_{13} \mathrm{H}_{16} \mathrm{ON}_{3} \mathrm{~S}_{2} \mathrm{O}$.
6.1.3.3. $\quad N$-(4-Oxo-2-thiazolin-2yl)- $N^{\prime}-p$-methylthioethylidenehydrazone (10c). Yield: $30 \%$; mp $155-6{ }^{\circ} \mathrm{C}$, recrystallizing solvent: ethanol $(95 \%) / \mathrm{H}_{2} \mathrm{O}$. IR $(\mathrm{KBr} /$ $\mathrm{cm}^{-1}$ ): $1595,1635,1730,2990 ;{ }^{1} \mathrm{H}$ NMR (DMSO- $d_{6} /$ ppm): $2.21\left(\mathrm{~s}, 3 \mathrm{H}, \mathrm{CH}_{3}\right), 3.70\left(\mathrm{~s}, 2 \mathrm{H}, \mathrm{CH}_{2}\right), 3.72(\mathrm{~d}$, $\left.J=12 \mathrm{~Hz}, 2 \mathrm{H}, \mathrm{CH}_{2}\right), 7.20(\mathrm{~m}, 4 \mathrm{H}$, aromatic), $7.61(\mathrm{t}$, $J=12 \mathrm{~Hz}, 1 \mathrm{H}, \mathrm{CH}) ;{ }^{13} \mathrm{C}$ NMR (DMSO- $\left.d_{6} / \mathrm{ppm}\right) \delta$ : $20.57,34.25,39.50,128.87,129.16,130.97,135.81$, 155.87, 174.20; $\mathrm{C}_{13} \mathrm{H}_{16} \mathrm{ON}_{3} \mathrm{~S}_{2} \mathrm{O}$.

\subsection{Biology}

6.2.1. Cytotoxicity assay. The cytotoxicity of the compounds was determined using BALB/c mice splenocytes $\left(5 \times 10^{6}\right.$ cells/well) cultured in 96-well plates in Dulbecco's Modified Eagle's Medium (DMEM, Sigma Chemical Co., St. Louis, MO) supplemented with 10\% of fetal calf serum (FCS; Cultilab, Campinas, SP, Brazil) and $50 \mu \mathrm{g} / \mathrm{mL}$ of gentamycin (Novafarma, Anápolis, GO, Brazil). Each compound was evaluated in three concentrations $(1,10$, and $100 \mu \mathrm{g} / \mathrm{mL})$, in triplicate. Cultures were incubated in the presence of ${ }^{3} \mathrm{H}$-thymidine $(1 \mu \mathrm{Ci} /$ well $)$ for $24 \mathrm{~h}$ at $37^{\circ} \mathrm{C}$ and $5 \% \mathrm{CO}_{2}$. After this period, the plate content was harvested to determine the ${ }^{3} \mathrm{H}$-thymidine incorporation using a beta-radiation counter ( $\beta$-matrix 9600, Packard). The toxicity of the compounds was determined comparing the percentage of ${ }^{3} \mathrm{H}$-thymidine incorporation (as indicator of cell viability) of drug-treated wells in relation to untreated wells. Non-toxic concentrations were defined as those causing a reduction of ${ }^{3} \mathrm{H}$-thymidine incorporation below $10 \%$ in relation to untreated controls.

6.2.2. Anti-T. cruzi assay. Epimastigotes of T. cruzi (Y and Colombian strains) were cultivated at $26^{\circ} \mathrm{C}$ in liver infusion tryptose medium (LIT) supplemented with $10 \%$ fetal calf serum, $1 \%$ hemin, $1 \% \mathrm{R} 9$ medium, and $50 \mu \mathrm{g} /$ $\mathrm{mL}$ gentamycin. Parasites $\left(10^{6}\right.$ cells $\left./ \mathrm{mL}\right)$ were cultivated in a fresh medium in the absence or in the presence of the compounds being tested or $0.01 \mathrm{mg} / \mathrm{mL}$ benznidazol (Rochagan, Roche). Cell growth was determined after 11 days of culture by counting viable forms in a hemacytometer. The compounds were prepared from a stock solution in DMSO. To determine the $\mathrm{IC}_{50}$, cultures of $\mathrm{Y}$ strain epimastigotes in the presence of different concentrations of the compounds were evaluated after 11 days as described above. $\mathrm{IC}_{50}$ calculation was carried out using non-linear regression on Prism 4.0 GraphPad software. Colombian strain $T$. cruzi trypomastigotes were obtained from culture supernatants of LCCMK2 cell line and placed in 96-well plates $\left(4 \times 10^{5} /\right.$ well) in DMEM supplemented with $10 \%$ FCS and $50 \mu \mathrm{g} / \mathrm{mL}$ gentamycin. Compounds were added at non-toxic concentrations, in triplicate. Viable parasites were counted in a hemacytometer $24 \mathrm{~h}$ after addition of compounds by way of trypan blue exclusion. The percentage of inhibition was calculated in relation to untreated cultures.

\section{Acknowledgments}

We thank the Brazilian National Research Council (CNPq), the Research Foundation of Pernambuco State 
(FACEPE), the Northwest Bank of Brazil, and FIOCRUZ for financial support. Our thanks are also due to the Department of Chemistry at the Federal University of Pernambuco (UFPE), for recording the ${ }^{1} \mathrm{H}$ NMR and IR spectra and elemental analyses of all compounds. The authors are thankful to Célio R. M. Nascimento for the help in technical works (CNPq \#500361/ 2004-5).

\section{References and notes}

1. Coura, J. R.; Castro, S. L. Mem. Inst. Oswaldo Cruz 2000 , 97, 3-21.

2. Aguirre, G.; Boiani, L.; Cerecetto, H.; Fernández, M.; González, M.; Denicola, A.; Otero, L.; Gambino, D.; Rigol, C.; Olea-Azar, C.; Faundez, M. Bioorg. Med. Chem. 2004, 12, 4885-4893; Aguirre, G.; Cabrera, E.; Cerecetto, H.; Di Maio, R.; González, M.; Seoane, G.; Duffaut, A.; Denicola, A.; Gil, M. J.; Martínez-Merino, V. Eur. J. Med. Chem. 2004, 39, 421-431.

3. Messeder, J. C.; Tinoco, L. W.; Figueroa-Villar, J. D.; Souza, E. M.; Santa Rita, R.; Castro, S. L. Bioorg. Med. Chem. Lett. 1995, 24, 3079-3084.

4. Chung, M. C.; Guido, R. V. C.; Martinelli, T. F.; Gonçalves, M. F.; Polli, M. C.; Botelho, K. C. A.; Varanda, E. A.; Colli, W.; Miranda, M. T.; Ferreira, E. I. Bioorg. Med. Chem. 2003, 11, 4779-4783.

5. Du, X.; Guo, C.; Hansell, E.; Doyle, P. S.; Caffrey, C. R.; Holler, T. P.; McKerrow, J. H.; Cohen, F. E. J. Med. Chem. 2002, 45, 2695-2707.

6. Almeida-de-Faria, M.; Freymuller, E.; Colli, W.; Alves, M. J. Exp. Parasitol. 1999, 92, 263-268.

7. Küçükgüzel, S. G.; Oruç, E. E.; Rollas, S.; Sabin, F.; Ozbek, A. Eur. J. Med. Chem. 2002, 37, 197-202.
8. Mamolo, M. G.; Falagiani, V.; Zampieri, D.; Vio, L.; Banfi, E.; Scilino, G. Il Farmaco 2003, 58, 631637.

9. Alves, A. J.; Leite, A. C. L.; Santana, D. P.; Beltrão, M. T.; Coelho, M. R.; Gayral, P. Il Farmaco 1993, 48, $1167-$ 1171.

10. Clough, J.; Chen, S.; Gordon, E. M.; Hackbarth, C.; Lam, S.; Trias, J.; White, R. J.; Candiani, G.; Donadio, S.; Romano, G.; Ciabatti, R.; Jacobs, J. W. Bioorg. Med. Chem. Lett. 2003, 13, 3409-3414.

11. Schmidt, A.; Krauth-Siegel, R. L. Curr. Top. Med. Chem. 2002, 2, 1239-1259.

12. Leite, A. C. L.; Santos, L. M. F.; Nascimento, D. D. S.; Sena, K. X. F. R.; Brondani, D. J. Acta farm. Bonaer. 2004, 23, 117-122.

13. Leite, A. C.; Santos, L. M. F.; Anjos, J. V.; Farias, M. P. A.; Souza, I. A.; Brondani, D. J. Heterocycl. Commun. 2003, 9, 73-76.

14. Dewar, M. J. S.; Zoebisch, E. G.; Healy, E. F.; Stewart, J. J. P. J. Am. Chem. Soc. 1985, 107, 3902-3909.

15. BioMedCAChe version 6.1, Copyright (@2000-2003 Fujitsu Limited, (1989-2000 Oxford Molecular Ltd, http://I www.CACheSoftware.com.

16. Choe, Y.; Brinen, L. S.; Price, M. S.; Engel, J. C.; Lange, M.; Grisostomi, C.; Weston, S. G.; Pallai, P. V.; Cheng, H.; Hardy, L. W.; Hartsough, D. S.; Mcmakin, M.; Tilton, R. F.; Baldino, C. M.; Craik, C. S. Bioorg. Med. Chem. 2005, 13, 2141-2156.

17. Morris, G. M.; Goodsell, D. S.; Halliday, R. S.; Huey, R.; Hart, W. E.; Belew, R. K.; Olson, A. J. J. Comp. Chem. 1998, 19, 1639-1662.

18. Sanner, M. F. J. Mol. Graphics Modell. 1999, 17, 57-61.

19. AutoDock, AutoGrid, AutoTors, Copyright (c)1991-2000, The Scripps Research Institute, http://www.scripps.edu/ $\mathrm{mb} /$ olson/doc/autodock.

20. Wallace, A. C.; Laskowski, R. A.; Thornton, J. M. Protein Eng. 1995, 8, 127-134. 